\title{
Pomalidomid w leczeniu chorych na szpiczaka plazmocytowego na podstawie analizy przypadku klinicznego
}

\author{
Pomalidomide in the treatment of patients \\ with plasma cell myeloma based on clinical case analysis
}

\author{
Lidia Gil, Łukasz Pruchniewski \\ Katedra i Klinika Hematologii i Transplantacji Szpiku, Uniwersytet Medyczny im. Karola Marcinkowskiego w Poznaniu
}

\begin{abstract}
Streszczenie
W ostatnich latach dokonat sie znaczacy postęp $w$ leczeniu szpiczaka plazmocytowego (PCM). Dzieki nowym terapiom opartym na lekach immunomodulujacych i inhibitorach proteasomu oraz przeszczepieniu autologicznych krwiotwórczych komórek macierzystych możliwe jest wydtużenie przeżycia wolnego od progresji choroby $i$ przeżycia catkowitego, ale nie wyleczenie. Wybór terapii postaci nawrotowej i opornej PCM powinien uwzglęniać skuteczność stosowanych leków, stan ogólny pacjenta i jego oczekiwania. W pracy przedstawiono przypadek pacjentki leczonej przez wiele lat z powodu nawrotowego PCM, u której dtugoletniq remisje z dobra jakościa życia uzyskano po zastosowaniu pomalidomidu z deksametazonem.
\end{abstract}

Słowa kluczowe: szpiczak plazmocytowy oporny/nawrotowy, pomalidomid, jakość życia

Hematologia 2017; 8, supl. A: A15-A18

\begin{abstract}
Significant progress has been made in the therapy of plasma cell myeloma (PCM) during last decades. With modern therapies based on proteasome inhibitors or immunomodulatory drugs and autologous stem cell transplantation we can prolong disease free and overall survival, but not cure the disease. Treatment of relapsed or refractory PCM should be based on efficacy of proposed drugs, performance status and patient expectation. The history of the patient treated for many years with relapsed PCM, with long-term hematological remission with good quality of life after pomalidomide with dexamethasone is presented in this paper.
\end{abstract}

Key words: refractory/relapsed multiple myeloma, pomalidomide, quality of life

Hematologia 2017; 8, supl. A: A15-A18

\section{Wprowadzenie}

Szpiczak plazmocytowy (PCM, plasma cell myeloma) jest przewlekłą chorobą nowotworową charakteryzującą się klonalnym rozrostem nowotworowych plazmocytów, zdolnych do wy- twarzania patologicznego białka monoklonalnego o strukturze immunoglobuliny lub jej fragmentu. Choroba występuje najczęściej u osób starszych, a chorzy w wieku poniżej 65 . lat stanowią około $30 \%$. Mimo niewątpliwych postępów w leczeniu PCM, wydłużenia przeżycia wolnego od choroby

Adres do korespondencji: Lidia Gil, Katedra i Klinika Hematologii i Transplantacji Szpiku, Uniwersytet Medyczny im. Karola Marcinkowskiego w Poznaniu, ul. Szamarzewskiego 84, 60-569 Poznań, e-mail: lidia.gil@skpp.edu.pl 
(PFS, progression-free survival) i przeżycia całkowitego (OS, overall survival) choroba pozostaje nieuleczalna. Szczególną grupę chorych stanowią pacjenci $z$ nawrotowym/opornym szpiczakiem, u których obserwuje się powikłania zależne od PCM oraz związane $z$ wcześniej prowadzonym leczeniem, dlatego znaczenie ma nie tylko skuteczność terapii, ale także jej bezpieczeństwo, tolerancja i wpływ na jakość życia.

W pracy przedstawiono analizę przypadku klinicznego dotyczącego długoletniego leczenia pacjentki z PCM $\mathrm{z}$ wielokrotnymi nawrotami choroby.

\section{Opis przypadku}

Chora urodzona w 1960 roku została skierowana na leczenie do kliniki hematologii i transplantacji szpiku w październiku 2007 roku. Podstawą rozpoznania były potwierdzony histopatologicznie naciek plazmocytarny w obrębie kręgu Th2, obecność $32 \%$ plazmocytów w szpiku oraz obecność białka monoklonalnego IgG kappa w surowicy w stężeniu $42 \mathrm{~g} / \mathrm{l}$. W ocenie radiologicznej kości opartej na rezonansie magnetycznym całego ciała stwierdzono obecność zmiany osteolitycznej ze złamaniem patologicznym w Th2. Prawidłowe stężenia albuminy i $\beta_{2}$-mikroglobuliny pozwoliły na określenie zaawansowania choroby jako stopień I według Międzynarodowego Indeksu Prognostycznego (ISS, International Staging System). W badaniu cytogenetycznym stwierdzono trisomię chromosomu 3 odpowiadającą ryzyku standardowemu PCM. Wyniki badań biochemicznych, w tym stężenie kreatyniny oraz morfologia krwi, były prawidłowe.

W leczeniu indukującym zastosowano talidomid (Tal) $z$ deksametazonem (Dex) systemowo oraz radioterapię na odcinek Th kręgosłupa. Uzyskano całkowitą remisję (CR) definiowaną jako brak białka monoklonalnego $\mathrm{w}$ surowicy i moczu $\mathrm{w}$ badaniu immunofiksacji, brak plazmocytów w szpiku, brak nowych zmian osteolitycznych w kościach. Po leczeniu obserwowano czuciową polineuropatię obwodową I stopnia według sNCI-CTC (sensory National Cancer Institute - Common Toxicity Criteria). W maju 2008 roku, po mobilizacji cyklofosfamidem (CTX) i czynnikiem stymulującym tworzenie kolonii granulocytów (G-CSF, granulocyte-colony stimulating factor), pobrano autologiczne krwiotwórcze komórki macierzyste do transplantacji (łącznie 3,8 × 106/kg komórek CD34+) i w lipcu tego samego roku przeprowadzono zabieg przeszczepienia po przygotowaniu melfalanem w dawce $200 \mathrm{mg} / \mathrm{m}^{2}$. Po transplantacji nie stosowano leczenia podtrzymującego. Pacjentka przez
2 lata otrzymywała kwas pamidronowy w infuzjach dożylnych co 4 tygodnie.

Do nawrotu choroby doszło w styczniu 2011 roku. Stwierdzono wzrost stężenia białka monoklonalnego w surowicy i obecność plazmocytów w szpiku (18\%), bez nowych ognisk osteolitycznych w kośćcu. Zastosowano wtedy leczenie bortezomibem w połączeniu $z$ doksorubicyną i Dex, uzyskując bardzo dobrą odpowiedź częściową (VGPR, very good partial response). Ze względu na brak rezerwy komórek CD34+ po pierwszej mobilizacji i niemożność uzyskania materiału do przeszczepienia mimo kolejnych dwóch prób mobilizacji zdecydowano o konsolidacji leczenia $z$ zastosowaniem przeszczepienia allogenicznych krwiotwórczych komórek macierzystych (allo-HSCT, allogeneic hematopoietic stem cell transplantation) od siostry w pełni zgodnej $\mathrm{w}$ układzie ludzkich antygenów leukocytarnych (HLA, human leukocyte antigen). Zabieg ten przeprowadzono po kondycjonowaniu o zredukowanej intensywności (fludarabina-cyklofosfamid-napromianianie całego ciała [TBI, total body irradiation]) w listopadzie 2011 roku. Nie obserwowano objawów choroby przeszczep przeciwko gospodarzowi (GvHD, graft-versus-host disease), ale $\mathrm{w}$ okresie potransplantacyjnym występowały powikłania infekcyjne górnych dróg oddechowych o etiologii bakteryjnej. Od września 2012 roku, przy całkowitym chimeryzmie dawcy, obserwowano powolny wzrost stężenia białka monoklonalnego. Zastosowano leczenie lenalidomidem (LEN) z Dex wraz $z$ infuzją limfocytów dawcy (łącznie 3 podania ze zwiększaną dawką limfocytów CD3+/kg mc.), uzyskując stabilizację choroby.

Do kolejnego, pełnoobjawowego nawrotu choroby doszło w październiku 2014 roku. Stwierdzono wówczas wzrost stężenia białka monoklonalnego w surowicy (IgG kappa 66 g/l), odsetka plazmocytów w szpiku (30\%) oraz nowe ogniska osteolityczne w lewej kości ramieniowej i lewym obojczyku. Strategię postępowania ustalono po omówieniu $z$ pacjentką możliwości terapeutycznych. Uwzględniając aktywny tryb życia, jaki prowadziła, zdecydowano o rozpoczęciu leczenia pomalidomidem $(\mathrm{POM}) \mathrm{z}$ Dex, zastosowano również radioterapię na zmiany kostne. Pomalidomid stosowano w rekomendowanej dawce $4 \mathrm{mg}$ przez 21 kolejnych dni w miesiącu w skojarzeniu $z$ Dex w dawce $40 \mathrm{mg}$ tygodniowo. U chorej nie obserwowano cytopenii wymagającej zmniejszenia dawki lub odstawienia leku, nie występowały też powikłania infekcyjne. Pacjentka pozostawała w CR do lipca 2017 roku. Obecnie jest poddana chemioterapii wielolekowej $z$ powodu kolejnej wznowy $z$ transformacją plazmoblastyczną. 


\section{Dyskusja}

Przedstawiona historia leczenia pacjentki odzwierciedla postęp w terapii PCM, jaki się dokonał $\mathrm{w}$ dwóch ostatnich dekadach. W terapii indukującej chora otrzymywała talidomid (Tal), należący do leków immunomodulujących (IMiD, immunomodulatory drugs), który przez wiele lat stanowił podstawę leczenia PCM w Polsce, początkowo $\mathrm{w}$ połączeniu ze steroidami, a następnie w skojarzeniu ze steroidami i CTX. Dzięki leczeniu zwykle udawało się uzyskać odpowiedź na poziomie $80 \%$, ale $z$ niskim odsetkiem CR. Terapia prowadzona całkowicie doustnie stanowiła jednak istotny postęp wobec wcześniej stosowanej chemioterapii według schematu VAD (winkrystyna, doksorubicyna, deksametazon) pod względem skuteczności i jakości życia. Najczęstsze i najpoważniejsze powikłania nadal stosowanego leczenia Tal obejmują polineuropatię obwodową oraz powikłania zakrzepowo-zatorowe. Polineuropatia, najczęściej o charakterze czuciowym, ma charakter nieodwracalny i skłania do zmiany leczenia w około $13 \%$. By zapobiegać powikłaniom zakrzepowo-zatorowym i je leczyć, stosuje się natomiast zalecenia uwzględniające czynniki ryzyka ich wystąpienia. Podstawą współczesnego leczenia indukującego u chorych na PCM jest zastosowanie inhibitorów proteasomu oraz IMiD. W Polsce stosuje się bortezomib (Bort) w połączeniu $z$ Dex i Tal lub CTX. Dzięki leczeniu uzyskuje się odpowiedź hematologiczną u ponad $80 \%$ chorych, z około $30 \%$ CR [1].

W opisywanym przypadku u chorej zastosowano wysokodawkową chemioterapię wspomaganą przeszczepieniem autologicznych krwiotwórczych komórek macierzystych (auto-HSCT, autologous hematopoietic stem cell transplantation) jako konsolidację uzyskanej odpowiedzi na leczenie indukujące. Takie postępowanie u pacjentów w wieku poniżej 65-70 lat i w dobrym stanie ogólnym wpływa na wydłużenie PFS (43,3 miesięcy $v$. 28,6 miesiące; $\mathrm{p}<0,001$ ), a także OS (4-letnie przeżycie: $86 \%$ v. $73 \%$; $\mathrm{p}=0,004) \mathrm{w}$ porównaniu $\mathrm{z}$ terapią konwencjonalną, co wykazano w licznych badaniach [2]. Dotyczy to także pacjentów $z$ grupy wysokiego ryzyka cytogenetycznego, choć wydaje się, że $\mathrm{w}$ tej grupie chorych korzystniejsze wyniki można uzyskać, przeprowadzając podwójną auto-HSCT [3]. U pacjentki przedstawionej w pracy nie stosowano po zabiegu auto-HSCT leczenia podtrzymującego. Współcześnie na podstawie wyników badań randomizowanych wykazano, że zastosowanie LEN po auto-HSCT wydłuża PFS (53 miesiące $v .27$ miesięcy; $\mathrm{p}<0,001)$, niezależnie od odpowiedzi uzyskanej za pomocą zabiegu przeszczepienia. Postępowanie takie jest nie tylko bardziej skuteczne od proponowanego wcześniej w takiej terapii Tal, ale także lepiej tolerowane. W grupie wysokiego ryzyka w terapii podtrzymującej warto raczej rozważyć Bort [4]. Zabieg auto-HSCT jest również rekomendowany jako zabieg ratunkowy w przypadku wznowy choroby, zwłaszcza jeśli dochodzi do niej po 18 miesiącach lub później po pierwszym zabiegu (odsetek odpowiedzi 55-97\%). Biorąc pod uwagę powyższe rekomendacje, w okresie mobilizacji komórek krwiotwórczych do auto-HSCT, należy dążyć do zebrania materiału wystarczającego na dwa takie zabiegi.

W okresie nawrotu u chorej zastosowano leczenie oparte na Bort, pierwszym reprezentancie inhibitorów proteasomu. W badaniach prospektywnych i retrospektywnych potwierdzono skuteczność tego leku w postaci opornej/nawrotowej zarówno w monoterapii (odsetek odpowiedzi 27\%), jak i terapii skojarzonej ze steroidami oraz Tal, CTX, Mel, LEN lub antracyklinami. Bortezomib można stosować u chorych na niewydolność nerek, działa szybko, ale może powodować polineuropatię oraz małopłytkowość.

Po uzyskaniu remisji hematologicznej u opisywanej pacjentki, wobec braku możliwości przeprowadzenia drugiej auto-HSCT, młodego wieku chorej, dostępności w pełni zgodnego dawcy rodzinnego przeprowadzono allo-HSCT od siostry. Zabieg allo-HSCT w PCM nie jest procedurą standardową, choć umożliwia całkowite wyleczenie choroby u około $30 \%$ pacjentów. Skuteczność leczenia warunkują dobrze udokumentowany efekt biologiczny przeszczepu przeciwko szpiczakowi (GvM, graft-versus-myeloma) oraz przeprowadzenie zabiegu w okresie dobrze kontrolowanej choroby (CR lub VGPR). Zastosowanie kondycjonowania o zredukowanej intensywności sprawia, że śmiertelność okołozabiegowa wynosi obecnie około $10 \%$, jednak zwiększa ryzyko nawrotu choroby [5]. Infuzja limfocytów dawcy umożliwia uzyskanie poprawy u 30-50\% chorych ze wznową po allo-HSCT, a odpowiedź ta może być spotęgowana przez IMiD. Lenalidomid, skuteczny u około $60 \%$ chorych $z$ opornym/nawrotowym PCM, poprzez wpływ na limfocyty T, komórki naturalnej cytotoksycznoiści (NK, natural killers), produkcję cytokin, intensyfikuje efekt GvM, nie zwiększając przy tym ryzyka powikłań, czyli choroby GvHD ani cytopenii. Po zastosowaniu takiego postępowania w opisywanym przypadku odpowiedź na leczenie utrzymywała się 3 lata.

W okresie kolejnego nawrotu zastosowano POM - najnowszy z IMiD. Jego mechanizm działania 
obejmuje hamowanie proliferacji nowotworowych plazmocytów, proliferacji i różnicowania osteoklastów, angiogenezy oraz aktywację limfocytów T i komórek NK. W prospektywnych badaniach randomizowanych udokumentowano skuteczność leku $\mathrm{u}$ chorych $\mathrm{z}$ opornym/nawrotowym PCM (odpowiedź całkowita ok. 33\%) w przypadku stosowania w przeszłości wielu linii leczenia $(\geq 2$, mediana 5$)$, w tym LEN, oraz obecności niekorzystnych cytogenetycznych czynników rokowniczych [6-8]. Lek stosowany doustnie w połączeniu $z$ Dex jest dobrze tolerowany i wpływa korzystnie na jakość życia [9]. Działania niepożądane w trakcie terapii POM wiążą się przede wszystkim $z$ mielosupresją. Ostatnie badania wskazują na bardzo dobre wyniki w zakresie wydłużenia PFS w przypadku skojarzenia POM $z$ karfilzomibem lub daratumumabem. U opisywanej chorej dzięki leczeniu uzyskano odpowiedź hematologiczną trwającą prawie 3 lata. W tym czasie mogła ona realizować swoje największe pasje, czyli podróże po świecie.

\section{Podsumowanie}

W podsumowaniu należy podkreślić znaczący postęp, jaki się dokonał w leczeniu chorych na PCM w ostatnich latach. W wyborze terapii postaci opornych i nawrotowych należy jednak brać pod uwagę nie tylko skuteczność leków ocenianą $\mathrm{w}$ badaniach randomizowanych, ale także oczekiwania pacjentów. Pomalidomid, nowoczesny IMiD, nie tylko wydłuża przeżycie chorych na PCM, ale również poprawia jakość ich życia.

\section{Piśmiennictwo}

1. Mateos M.V., San Miguel J.F. How should we treat newly diagnosed multiple myeloma patients? Hematology Am. Soc. Hematol. Educ. Program 2013; 2013: 488-495.

2. Attal M., Lauwers-Cances V., Hulin C. i wsp. Autologous transplantation for multiple myeloma in the era of new drugs: phase III study of the Intergroupe Francophone Du Myelome. Blood 2015; 126: abstrakt 391.

3. Dispenzieri A. Myeloma: management of the newly diagnosed high-risk patient. Hematology Am. Soc. Hematol. Educ. Program 2016; 2016: 485-494.

4. McCarthy P.L., Holstein S.A., Petrucci M.T. i wsp. Lenalidomide maintenance after autologous stem-cell transplantation in newly diagnosed multiple myeloma: a meta-analysis. J. Clin. Oncol. 2017; 35: 3279-3289.

5. Dhakal B., Vesole D.H., Hari P.N. Allogeneic stem cell transplantation for multiple myeloma: is there a future? Bone Marrow Transplant. 2016; 51: 492-500.

6. San Miguel J., Weisel K., Moreau P. i wsp. Pomalidomide plus low-dose dexamethasone versus high-dose dexamethasone alone for patients with relapsed and refractory multiple myeloma (MM-003): a randomised, open-label, phase 3 trial. Lancet Oncol. 2013; 14: 1055-1066.

7. San Miguel J.F., Weisel K.C., Song K.W. i wsp. Impact of prior treatment and depth of response on survival in MM-003, a randomized phase 3 study comparing pomalidomide plus low-dose dexamethasone versus high-dose dexamethasone in relapsed/refractory multiple myeloma. Haematologica 2015; 100: 1334-1339.

8. Goldschmidt H., Moreau P., Ludwig H. i wsp. Cytogenetics and long-term survival of patients with refractory or relapsed and refractory multiple myeloma treated with pomalidomide and low-dose dexamethasone. Haematologica 2015; 100: 1327-1333.

9. Weisel K., Dimopoulos M., Song K.W. i wsp. Pomalidomide and low-dose dexamethasone improves health-related quality of life and prolongs time to worsening in relapsed/refractory patients with multiple myeloma enrolled in the MM-003 randomized phase III trial. Clin Lymphoma Myeloma Leuk. 2015; 15: 519-530. 